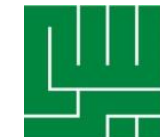

\title{
Hubungan Psychological Capital Dan Perilaku Kerja Inovatif Di Industri Kreatif: Studi Pada Karyawan Perusahaan Xyz
}

\section{The Relationship between Psychological Capital and Innovative Work Behavior in Creative Industry : A Study among Employees of XYZ Company}

\author{
Dila Fitriza Rulevy ${ }^{1} \&$ Endang Parahyanti ${ }^{2}$ \\ Fakultas Psikologi, Universitas Indonesia, Depok 16424, Indonesia \\ Email:dilafitriza@gmail.com; parahyanti@gmail.com
}

KATA KUNCI

KEYWORDS

ABSTRAK

ABSTRACT perilaku positif organisasi, psychological capital, perilaku kerja inovatif, industry kreatif

positive organization behavior, psychological capital, innovative work behavior, creative industry, .

Penelitian dilakukan untuk mengetahui gambaran mengenai hubungan antara psychological capital dan perilaku kerja inovatif di industri kreatif perusahaan XYZ. Hal ini didasari oleh perkembangan industri kreatif yang mengalami peningkatan pada beberapa tahun belakangan, sehingga dibutuhkannya inovasi. Pendekatan psychological capital dapat dilakukan untuk unggul dalam kompetisi berkelanjutan yang didasarkan pada fakta bahwa kebanyakan organisasi saat ini tidak menyadari potensi penuh dari sumber daya manusianya. Psychological capital dapat menjadi salah satu faktor internal yang berperan terhadap perilaku kerja inovatif yang merupakan inovasi pada tingkat individu. Pengukuran psychological capital menggunakan alat ukur Psychological Capital Questionaire (PCQ-12) yang disusun oleh Luthans, Youssef, dan Avolio (2007). Pengukuran perilaku kerja inovatif menggunakan alat ukur Innovative Work Behavior Scale (IWB Scale) yang disusun oleh Janssen (2000) dan telah diadaptasi oleh Damayanti (2013). Partisipan penelitian berjumlah 398 karyawan perusahaan XYZ. Melalui teknik statistik Pearson Correlation, diketahui bahwa terdapat hubungan positif yang signifikan antara psychological capital dan perilaku kerja inovatif $(r=0.448, n=398, p<0.01$, two tailed)..

This research was conducted to find the correlation between psychological capital and innovative work behavior among XYZ company's employees. It was based on the development of creative industries which have increased in recent years, so it took innovation to deal with that condition. This new psychological capital approach to gaining sustained competitive advantage is based on the generally accepted fact that most organizations today are not realizing the full potential of their human resources. Psychological capital can be one of internal factors that may contribute to innovative work behavior which is an innovation on 
individual level. Psychological capital was measured by using an instrument named Psychological Capital Questionaire (PCQ-12) made by Luthans, Youssef, and Avolio (2007). Innovative work behavior was measured by using Innovative Work Behavior Scale (IWB Scale) made by Janssen (2000) and adapted by Damayanti (2013). Participants of this research were 398 employees of XYZ company. The Pearson Correlation indicates positive significant correlation between psychological capital and innovative work behavior ( $r=0.448, n=398, p<0.01$, two tailed).

\section{PENDAHULUAN}

Pada era globalisasi ini, ide-ide dan inovasi individu atau kelompok khususnya di bidang ekonomi terus mengalami perkembangan yang dapat memberikan luaran dalam berbagai bentuk dan terus mengalami peningkatan kualitas seiring berjalannya waktu. Berkembangnya ide-ide dan inovasi ini menimbulkan persaingan ekonomi khususnya di negara berkembang yang memperluas akses bisnis mereka yang kompetitif. Hal ini dibuktikan dengan kenyataan bahwa di Indonesia, peningkatan ide dan inovasi menyebabkan semakin meningkatnya peranan industri kreatif yang telah berkembang sejak 10 tahun terakhir (Ghazali, 2015).

Berdasarkan data dari Tim Studi Ekonomi Kreatif, Kementerian Pariwisata dan Ekonomi Kreatif 2014, selama beberapa tahun belakangan, tercatat bahwa terdapat peningkatan kontribusi dari industri kreatif terhadap Produk Domestik Bruto (PDB) Indonesia. Industri kreatif telah berkontribusi sebanyak $7 \%$ terhadap PDB di Indonesia (program.industrikreatif.net). Industri kreatif menyerap 8,6 juta orang atau 7,9\% dari tenaga kerja Indonesia, dan menjadi sektor kelima terbesar setelah pertanian, kehutanan, perikanan dan peternakan, perdagangan, hotel, dan restoran, jasa kemasyarakatan dan industri pengolahan (Suara Pembaruan, 2012). Bukti peningkatan ini sesuai dengan gagasan oleh Cunningham et al. (2008) yang mengatakan bahwa industri kreatif memiliki nilai ekonomi yang dinamis.

Melihat kondisi industri kreatif di Indonesia yang terus berkembang, kemampuan pihak di dalamnya untuk berinovasi tentunya memiliki peran penting dalam mempertahankan dan mengembangkan industrinya guna menyesuaikan diri dengan perubahan atau perkembangan kompetitornya. Hal ini didukung oleh Miron, Erez, dan Naveh (dalam Schermuly, 2013) yaitu untuk dapat bertahan dalam ruang lingkup bisnis global, organisasi harus secara terus menerus mengembangkan produk dan pelayanan yang berinovasi.

Waenink (2012) mengatakan inovasi memiliki hubungan erat dengan karyawan, dimana masing-masing fase dalam inovasi beserta kegiatan yang terkait memerlukan berbagai perilaku dari karyawan secara individu. Berkaitan dengan hal tersebut, perilaku kerja inovatif (innovative work behavior) muncul sebagai suatu bentuk inovasi pada tingkat individu (Waenink, 2012). Janssen (2000) mengikuti Scott dan Bruce (1994) memberikan pemahaman mengenai perilaku kerja inovatif berdasarkan proses atau tahapannya yang diawali dengan adanya idea generation sehingga memunculkan sebuah ide yang baru dan berguna dalam domain tertentu. Tahapan dari proses inovasi berikutnya yaitu idea promotion terhadap pihak-pihak yang memiliki potensi. Ketika seorang pekerja telah menggenerasikan sebuah ide, maka individu tersebut telah terikat dalam aktivitas sosial untuk mencari teman, backers, sponsor yang mendukung ide, atau membangun koalisi pendukung yang dapat memberikan kekuatan di balik hal tersebut (Galbraith, 1982; Kanter, 1988 dalam Janssen, 2000). Tugas akhir dari tahapan proses inovasi adalah idea realization 
dengan menghasilkan sebuah prototip atau model dari inovasi yang dapat dialami dan sangat dapat diaplikasikan dalam sebuah peran kerja, grup atau organisasi secara keseluruhan (Kanter, 1988 dalam Janssen, 2000). Bagi organisasi yang membutuhkan perilaku kerja inovatif pada karyawannya, tentunya penting untuk mempelajari faktorfaktor yang berperan di dalamnya sehingga dapat memunculkan perilaku tersebut. Faktor internal yang berasal dari karyawan secara individu dipelajari memiliki peran paling penting sebagai faktor perilaku kerja inovatif (West \& Farr, 1989; Ramamoorthy et al., 2005; Dörner, 2012). West dan Farr (1989) memiliki keyakinan bahwa terdapat banyak hal yang dapat dipelajari dari fokus terhadap perilaku inovatif pada individu. Salah satu aspek individual yang sangat membantu munculnya perilaku inovatif pada individu dapat dipelajari melalui perspektif psikologis yang merupakan faktor internal (West \& Farr, 1989).

Luthans, Youssef, dan Avolio (2007) mengajukan sebuah konsep baru yang menarik dan menekankan pada perspektif psikologis yaitu psychological capital, berasal dari manusia dan dapat diinvestasikan dan dikembangkan untuk unggul dalam kompetisi yang berkelanjutan melalui diri individu. Hal ini didasari anggapan bahwa saat ini, untuk mengelola organisasi secara efektif dibutuhkan paradigma baru dimana keunggulan dan manfaat dari kompetitif yang berkelanjutan tidak bisa lagi didasarkan pada sumber daya tradisional atau langka, seperti fisik, keuangan, dan teknologi, melainkan fokus terhadap sumber daya manusia yang dimiliki (Luthams, Youssef, \& Avolio, 2007). Psychological capital merupakan suatu keadaan psikologis yang positif pada individu yang berkontribusi pada kemajuan dirinya dan terdiri dari beberapa komponen: (1) memiliki kepercayaan diri untuk menghadapi dan memberikan usaha yang diperlukan untuk menyelesaikan pada tugas yang menantang, (2) memiliki atribusi positif untuk kesuksesan masa kini dan masa mendatang, (3) tekun dalam mencapai tujuan, dan mengarahkan langkah menuju tujuan guna mencapai kesuksesan, dan (4) ketika dilanda masalah dan kesulitan, individu dapat menyeimbangkan dan bangun kembali untuk mencapai kesuksesan (Luthans, Youssef \& Avilio, 2007). Alasan penggabungan empat konstruk yaitu efficacy, optimism, hope, dan resiliency menjadi satu konstruk psychological capital adalah sudah terbuktinya bahwa banyak sumber daya psikologis dan personalyang saling berhubungan satu sama lain, dimana ketika individu memiliki satu sumber daya yang tinggi, seringkali akan tinggi pula pada sumber daya yang lain, sehingga dapat dikatakan bahwa sumber daya tesebut bereaksi secara harmoni (Cozzarelli, 1993). Peretz, Binyamin dan Carmeli (2011) menyarankan bahwa kondisi positive psychological, seperti konsep psychological capital dalam ruang lingkup kerja dapat meningkatkan motivasi karyawan yang dapat menanamkan keterikatan pada perilaku kerja inovatif.

Teori mengenai psychological capital menunjukkan bahwa sumber positif psikologis dari efficacy, hope, resiliency, dan optimism tidak dapat bertindak maksimal apabila diteliti secara terpisah, sebaliknya mereka menyediakan dukungan untuk satu sama lain melalui mekanisme bersama yang mendasari, sehingga mereka harus dipelajari secara kolektif (Luthans, Avolio, Avey, \& Norman, 2007). Oleh karena itu, peneliti memutuskan untuk meneliti hubungan psychological capital sebagai konstruk kesatuan dan perilaku kerja inovatif. Meskipun diketahui bahwa akan lebih baik ketika psychological capital diteliti secara kesatuan, hubungan tiap komponen di dalamnya juga dapat diteliti untuk mengetahui komponen mana yang memiliki hubungan paling kuat terhadap perilaku kerja inovatif, sehingga dapat dilakukan pengembangan terkait komponen psychological capital mengikuti masingmasing cara pengembangannya yang dikembangkan oleh Luthans, Youssef, dan Avolio (2007). Hal ini didukung oleh 
penelitian Sweetman, et al. (2010) yang melihat hubungan psychological capital dengan kinerja kreatif baik psychological capital secara kesatuan maupun tiap komponennya. Hasil penelitian menunjukkan bahwa tiap komponen psychological capital memiliki hubungan yang signifikan dengan kinerja kreatif.

Moegni dan Sulistiawan (2012) telah melakukan penelitian mengenai hubungan psychological capital dengan perilaku kerja inovatif dan hasilnya menunjukkan tidak terdapat hubungan yang signifikan di antara keduanya. Menurut Moegni dan Sulistiawan (2012), limitasi penelitian ini salah satunya adalah subjek penelitian yang merupakan Pegawai Negeri Sipil (PNS). Mereka berpendapat bahwa perilaku inovasi cenderung kurang begitu tampak pada organisasi pemerintahan. Menurut $\mathrm{Ng}$ dan Fieldman (2010, dalam Moegni \& Sulistiawan, 2012), di dalam organisasi pemerintahan terdapat birokrasi yang cukup kuat, kaku dan tidak mampu mengakomodir perkembangan zaman.

Penelitian serupa yang dilakukan oleh Abbas dan Raja (2015) mengenai hubungan psychological capital dengan perilaku kerja inovatif menunjukkan terdapatnya hubungan yang positif secara signifikan di antara keduanya. Berbeda dengan penelitian yang dilakukan oleh Moegni dan Sulistiawan (2012), populasi penelitian ini adalah beragam karyawan yang bekerja di bank, kementerian, perusahaan telekomunikasi, dan perusahaan tekstil di Pakistan. Hasil penelitian Abbas dan Raja (2015) menunjukkan bahwa terdapat hubungan yang positif dan signifikan antara psychological capital dan perilaku kerja inovatif. Namun, penelitian tersebut memiliki beberapa limitasi, salah satunya industri-industri pada sampel penelitian yang dirasa tidak memiliki tingkat kebutuhan inovasi yang tinggi. Oleh karena itu, Abbas dan Raja (2015) menyarankan penelitian berikutnya untuk meneliti hubungan psychological capital dan perilaku kerja inovatif pada industri yang sangat membutuhkan inovasi bagi pertumbuhan organisasi berkelanjutan.

Berdasarkan anggapan-anggapan di atas, peneliti tertarik untuk melihat hubungan antara psychological capital dengan perilaku kerja inovatif di industri kreatif, dikarenakan keadaan industri kreatif yang dinamis melihat fakta-fakta yang telah dipaparkan di atas, sehingga dirasa memerlukan perilaku kerja inovatif untuk dapat menyesuaikan dengan perkembangan.

\section{Dinamika psychological capital dan} perilaku kerja inovatif

Keadaan industri kreatif yang memiliki nilai ekonomi yang dinamis dan terus mengalami peningkatan terhadap perekonomian negara, khususnya di Indonesia menekankan pihak yang terlibat di dalamnya untuk dapat berlomba dengan kompetitornya guna menyesuaikan diri dengan ruang lingkup bisnis global melalui penerapan inovasi. Inovasi memiliki hubungan erat dengan keterlibatan karyawan secara individu, dikarenakan fase inovasi yang berbeda dan aktivitas di dalamnya membutuhkan tindakan dari karyawan. Perilaku kerja inovatif muncul sebagai inovasi yang dilakukan pada tingkat individu. Penelitian-penelitian sebelumnya menemukan bahwa faktor internal yang berasal dari karyawan secara individu memiliki peran paling penting yang berperan terhadap perilaku kerja inovatif (West \& Farr, 1989; Ramoorthy et al., 2005; Dörner, 2012). Berkaitan dengan hal tersebut, West dan Farr (1989) memiliki keyakinan bahwa terdapat banyak hal yang dapat dipelajari dari fokus terhadap perilaku inovatif pada individu. Salah satu aspek individual yang sangat membantu munculnya perilaku inovatif pada individu dapat dipelajari melalui perspektif psikologis (West \& Farr, 1989).

Luthans, Youssef, dan Avolio (2007) mengajukan sebuah konsep baru yang menarik dan menekankan pada perspektif psikologis yaitu psychological capital, berasal dari manusia dan modal sosialnyadapat diinvestasikan dan 
dikembangkan untuk unggul dalam kompetisi yang berkelanjutan melalui diri individu. Luthans, Youssef, dan Avolio (2007) menjelaskan secara spesifik bahwa psychological capital terdiri dari empat komponen yang masing-masing telah ditemukan secara empiris dapat memprediksi kinerja dan kepuasan yang lebih baik daripada komponen individu lainnya. Perets, Binyamin dan Carmeli (2011) mengatakan bahwa kondisi positive psychological, seperti konsep psychological capital dalam ruang lingkup kerja dapat meningkatkan motivasi karyawan yang dapat menanamkan keterikatan pada perilaku kerja inovatif. Dalam hal ini, peneliti melihat bahwa psychological capital dengan empat konstruk psikologis penting pada individu dapat menjadi salah satu dari beberapa faktor internal karyawan secara individu yang dapat berperan terhadap perilaku kerja inovatif.Berdasarkan kesimpulan dari penemuan dan gagasan di atas, berikut ini adalah hipotesis penelitian yang peneliti akan lakukan:

$\mathbf{H}_{1}$ : Terdapat hubungan yang signifikan antara psychological capital dan perilaku kerja inovatif karyawan di industri kreatif perusahaan XYZ.

Penelitian sebelumnya yang dilakukan oleh Abbas dan Raja (2015) menemukan bahwa psychological capital memiliki hubungan positif yang signifikan terhadap perilaku kerja inovatif pada populasi penelitian yang tersebar pada perusahaan-perusahaan besar di Pakistan. Hal ini membuat peneliti tertarik untuk melihat bagaimana psychological capital sebagai konstruk yang dikatakan dapat memprediksi pencapaian tujuan dan kinerja berperan terhadap perilaku kerja inovatif yang dibutuhkan pada industri kreatif di Indonesia. Meskipun diketahui bahwa akan lebih baik ketika psychological capital diteliti secara kesatuan, hubungan tiap komponen di dalamnya juga dapat diteliti untuk mengetahui komponen mana yang memiliki hubungan paling kuat terhadap perilaku kerja inovatif, sehingga dapat dilakukan pengembangan terkait komponen psychological capital mengikuti masingmasing cara pengembangannya yang dikembangkan oleh Luthans, Youssef, dan Avolio (2007). Hal ini didukung oleh penelitian Sweetman, et al. (2010) yang melihat hubungan psychological capital dengan kinerja kreatif baik psychological capital secara kesatuan maupun tiap komponennya. Hasil penelitian menunjukkan bahwa tiap komponen psychological capital memiliki hubungan yang signifikan dengan kinerja kreatif. Berdasarkan hal di atas, peneliti berusaha untuk mengkaitkan tiap komponen psychological capital dengan perilaku kerja inovatif untuk mengetahui komponen psychological capital apa yang memiliki hubungan paling kuat dengan perilaku kerja inovatif.

$\mathbf{H}_{2}$ : Self efficacy memiliki hubungan yang lebih kuat dibandingkan hope, resiliency, dan optimism terhadap perilaku kerja inovatif karyawan di industri kreatif perusahaan XYZ.

$\mathbf{H}_{3}$ : Hope memiliki hubungan yang lebih kuat dibandingkan self efficacy, resiliency, dan optimism terhadap perilaku kerja inovatif karyawan di industri kreatif perusahaan XYZ.

$\mathbf{H}_{4}$ : Resiliency memiliki hubungan yang lebih kuat dibandingkan self efficacy, hope, dan optimism terhadap perilaku kerja inovatif karyawan di industri kreatif perusahaan XYZ.

$\mathbf{H}_{5}$ : Optimism memiliki hubungan yang lebih kuat dibandingkan self efficacy, hope, dan resiliency terhadap perilaku kerja inovatif karyawan di industri kreatif perusahaan XYZ.

Pada kaitannya dengan perilaku kerja inovatif, self efficacy yang lebih tinggi memungkinkan untuk melihat tantangan sebagai sesuatu yang dapat diatasi dengan kompetensi yang cukup dan usaha, sehingga mereka cenderung memilih untuk 
mengeksplorasi peluang dan menggenerasikan ide-ide baru untuk mengatasi hal tersebut. Individu yang memiliki optimisme tinggi cenderung akan bersikap positif untuk berusaha melakukan sebuah perubahaan ke arah yang lebih baik, melihat kesempatan-kesempatan di masa depan, dan fokus dalam mengambil kesempatan-kesempatan tersebut. Individu yang memiliki hope tinggi pada umumnya merupakan pemikir yang mandiri dan otonom (Luthans, Youssef, \& Avolio, 2007). Pada kaitannya dengan perilaku kerja inovatif, individu dengan hope yang tinggi dapat akan mengerahkan segala usahanya dan membuat perencanaan yang inovatif untuk memperoleh kesuksesan. Perilaku kerja inovatif membutuhkan dorongan internal yang gigih untuk bergerak melewati tantangan dan halangan yang ada khususnya pada perkembangan industri kreatif, serta untuk beradaptasi dengan perubahan lingkungan secara umum. Resiliency yang tinggi dapat memberikan mekanisme yang dibutuhkan oleh individu untuk dapat bertahan menghadapi perubahan dan kebutuhan dalam memecahkan masalah secara inovatif (Luthans, Youssef, \& Avolio, 2007).

\section{METODE PENELITIAN}

Penelitian ini terdiri dari dua variabel yaitu, psychological capital dan perilaku kerja inovatif. Berdasarkan Kumar (1999) tipe penelitian dibagi atas tiga pendekatan, yaitu berdasarkan aplikasi (application), tujuan (objective), dan tipe informasi yang diperoleh (type of information sought). Tipe penelitian pada penelitian ini termasuk dalam penelitian aplikatif, penelitian korelasional dan penelitian kuantitatif. Desain penelitian dapat dilihat dari tiga pendekatan, yaitu berdasarkan number of contacts, reference period, dan nature of investigation (Kumar, 1999). Penelitian ini menggunakan desain penelitian retrospektif dan nonexperimental.

Responden penelitianmerupakan karyawan dari salah satu industri kreatif ranah penerbitan dan percetakan, yaitu perusahaan XYZ pada tingkat managerial dan staff. Responden penelitian berasal dari 7 departemen yang berada di kantor perusahaan XYZ. Perusahaan XYZ memiliki nilai inovatif di dalam salah satu nilai utamanya, yaitu kompetitif. Responden penelitian harus memenuhi persyaratan yaitu memiliki status karyawan tetap dengan lama bekerja minimal satu tahun.Berdasarkan hasil cleaning data diperoleh besaran sampel yang dapat diolah yaitu sebanyak 398 responden.

Pada penelitian ini, alat ukur yang digunakan yaitu alat ukur psychological capital dan alat ukur perilaku kerja inovatif. Alat ukur psychological capital menggunakan Psychological Capital Questionnaire (PCQ-12) yang dikembangkan oleh Luthans, Youssef, dan Avolio (2007). PCQ-12 terdiri dari 12 item yang merupakan short version dari PCQ 24 item dan mengukur empat komponen, yaitu self efficacy, hope, resiliency, dan optimism. Alat ukur ini memiliki nilai cofficient-alpha sebesar 0.828 dan nilai corrected item-total correlation di atas 0.2. Alat ukur perilaku kerja inovatif menggunakan Innovative Work Behaviore Scale (IWB Scale) yang dikembangkan oleh Janssen (2000) dan telah diadaptasi oleh Damayanti (2013). IWB Scale terdiri dari 9 item yang mengukur 3 tahapan perilaku kerja inovatif, yaitu idea geenration, idea promotion, dan idea realization. Alat ukur ini memiliki nilai cofficient-alpha sebesar 0.914 dan nilai corrected item-total correlation di atas 0.2 .

Seluruh instrumen pengukuran dalam penelitian inimenggunakan metode pengerjaan self-report dengan menggunakan skala likert type yang terdiri atas 6 pilihan jawaban. Pada alat ukur PCQ12, masing-masing item diisi dengan memilih satu di antara enam skala Likert type, yaitu skala 1 untuk "sangat tidak setuju", skala 2 untuk "tidak setuju", skala 3 untuk "agak tidak setuju", skala 4 untuk "agak setuju", skala 5 untuk "setuju", dan skala 6 untuk "sangat setuju". Pada alat 
ukur IWB Scale, masing-masing itemdiisi Likert type, yaitu skala 1 untuk "belum pernah sama sekali", skala 2 untuk "sudah mulai sesekali", skala 3 untuk "mulai agak sering", skala 4 untuk "agak sering", skala 5 untuk "hampir selalu", dan skala 6 untuk "selalu menampilkan". Pada awalnya, skala Likert berdasarkan IWB Scale oleh Janssen (2000) terdiri dari 7 pilihan jawaban yang mengacu kepada frekuensi tidak pernah hingga selalu, namun peneliti melakukan modifikasi jumlah skala menjadi 1 hingga 6 untuk menghindari jawaban tengah pada responden.

Teknik statistik yang digunakan untuk melakukan pengolahan data antara lain teknik statistik deskriptif, pearson correlation, T-test dan ANOVA (Analysis of Variance).

\section{ANALISIS \& HASIL}

Responden dalam penelitian ini adalah karyawan perusahaan XYZ yang terbagi atas tujuh departemen dan berada pada layer 3, 4, dan 5 yang diklasifikasikan berdasarkan tingkah managerial dan staff. Total responden dalam penelitian ini sebanyak 398 orang responden. Pada aspek jenis kelamin, responden penelitian sebagian besar berjenis kelamin laki-laki dengan memilih satu di antara enam skala dengan persentase sebesar $60.6 \% \quad$ (241 orang), sedangkan pada aspek usia, responden penelitian sebagian besar berada pada rentang usia 25-44 tahun dengan persentase $77.4 \%$ (308 orang). Pada aspek pendidikan, sebagian besar responden telah menempuh pendidikan pada tingkat sarjana dengan persenrase $70.6 \%$ (281 orang). Jika dilihat dari aspek responden yang berhubungan dengan perusahaan XYZ, sebagian besar responden penelitian berada pada tingkat jabatan staff dengan persentase $65.6 \%$ (261 orang) dan berasal dari departemen bisnis dengan persentase $34.7 \%$ (138 orang). Lebih lanjut lagi, jika dilihat dari lamanya bekerja, sebagian besar responden penelitian telah bekerja di peruahaan XYZ dalam rentang waktu lebih dari 10 tahun dengan persentase $53.3 \%$ (212 orang).

Pada variabel penelitian, diperoleh rata-rata skor total perilaku kerja inovatif pada responden penelitian sebesar 29.71 dengan skor terendah yaitu 10 dan skor tertinggi yaitu 54.Pada psychological capital, diperoleh mean rata-rata skor total psychological capital pada responden penelitian sebesar 52.67 dengan skor terendah yaitu 37 dan skor tertinggi yaitu 71.

Tabel 1. Hasil Uji Korelasi antara Psychological Capital dengan Perilaku Kerja Inovatif

\begin{tabular}{lcc}
\hline Variabel & $\mathrm{r}$ & $\mathrm{Sig}(p)$ \\
\hline $\begin{array}{l}\text { psychological capital } \\
\text { dan perilaku kerja inovatif }\end{array}$ & .448 & $.000^{*}$ \\
\hline \multicolumn{2}{c}{$* 0.01$ level, (two-tailed) }
\end{tabular}

Berdasarkan penghitungan korelasi kedua variabel, ditemukan hubungan positif dan signifikan antara psychological capital dan perilaku kerja inovatif karyawan di industri kreatif perusahaan XYZ $(r=0.448$, $n=398, p<0.01$, two tailed), sehingga hasil ini menerima $\mathrm{H}_{1}$

Tabel 2. Hubungan Tiap Komponen Psychological Capital terhadap Perilaku Kerja inovatif

\begin{tabular}{lcc}
\hline \multicolumn{1}{c}{ Komponen } & $\mathrm{r}$ & $\operatorname{Sig}(p)$ \\
\hline Self efficacy & .444 & $.000^{*}$ \\
Hope & .283 & $.000^{*}$ \\
Resiliecy & .252 & $.000^{*}$ \\
Optimism & .197 & $.000^{*}$ \\
\hline
\end{tabular}


Berdasarkan pengujian yang sama, ditemukan hubungan yang positif dan signifikan antara tiap komponen psychological capital dan perilaku kerja inovatif dengan dengan empat karakteristik responden. Sebaliknya, kedua variabel silence memiliki hubungan. Pada komponen self efficacy, $r=0.444, n=398$, $p<.01$, two-tailed, pada komponen hope, $r$ $=0.283, n=398, p<.01$, two-tailed, pada komponen resiliency, $r=0.252, n=398, p$ $<.01$, two-tailed dan pada komponen optimism, $r=.197, n=398, p<.01$, twotailed. Berdasarkan nilai koefisien korelasi ( $r)$, dapat dilihat bahwa self efficacy memiliki hubungan lebih kuat dengan perilaku kerja inovatif yang dignifikan pada LoS 0.01 ( $r=0.444, n=398, p<0.01$, two tailed). Hal ini menunjukkan bahwa self efficacy merupakan komponen psychological capital yang memiliki hubungan lebih kuat terhadap perilaku kerja inovatif di industri kreatif perusahaan XYZ dibandingkan komponen lainnya, sehingga hasil ini menerima $\mathrm{H}_{2}$ dan menolak $\mathrm{H}_{3}, \mathrm{H}_{4}$, dan $\mathrm{H}_{5}$.

Setelah melakukan analisis mengenai hubungan kedua variabel, peneliti melakukan analisis mengenai kedua variabel pada penelitian ini dan data demografis yang berkaitan dengan variabel perilaku kerja inovatif menggunakan teknik statistik independent-sample t-test dan ANOVA (analysis of variance). Melalui teknik statistik tersebut, peneliti dapat mengetahui perbedaan rata-rata yang signifikan pada beberapa aspek demografis.

Tabel 3. Perbedaan Perilaku Kerja Inovatif Berdasarkan Aspek Demografis

\begin{tabular}{lccc}
\hline \multicolumn{1}{c}{ Aspek Demografis } & $\mathrm{N}$ & $\mathrm{M}$ & Sig $(p)$ \\
\hline Jenis Kelamin & & & \\
Laki-laki & 241 & 31.54 & $\mathrm{t}=4.848$ \\
Perempuan & 157 & 26.90 & $\mathrm{p}=.000^{*}$ \\
Pendidikan & & & \\
SMA & 41 & 26.73 & $\mathrm{~F}=5.575$ \\
Diploma & 58 & 26.31 & $\mathrm{p}=.001^{*}$ \\
Sarjana & 281 & 30.63 & \\
Magister & 18 & 33.17 & \\
Jabatan & & & $\mathrm{t}=3.471$ \\
Managerial & 137 & 31.99 & $\mathrm{p}=.001^{*}$ \\
Staff & 261 & 28.52 & $\mathrm{~F}=2.792$ \\
Departemen & & & $\mathrm{p}=.011^{*}$ \\
Publishing WC & 92 & 27.84 & \\
GIM & 43 & 30.58 & \\
SIM & 61 & 3079 & \\
Media Service & 29 & 35.59 & \\
Bisnis & 138 & 29.21 & \\
HR\&GA & 32 & 29 & \\
SKG & 3 & 27 & \\
\hline$* p<0.05 ; * *<0.01$ level, (two-tailed) & & \\
& & & \\
\hline
\end{tabular}

Teknik statistik Independent Sampel T-test menunjukan bahwa terdapat perbedaan rata-rata yang signifikan pada perilaku kerja inovatifjika ditinjau berdasarkan jenis kelamin, $t(397)=4.848$, $p<0.01$. Berdasarkan aspek demografis ini, responden yang memiliki jenis kelamin laki-laki memiliki rata-rata skor total perilaku kerja inovatif yang paling tinggi $(M=31.51) . \quad$ Teknik statistik 
ANOVAmenunjukan bahwa terdapat perbedaan rata-rata yang signifikan pada perilaku kerja inovatifjika ditinjau berdasarkan pendidikan, $F(2,395)=5.575$, $p<0.05$. Berdasarkan aspek demografis ini, responden yang memiliki tingkat pendidikan akhir magister memiliki ratarata skor total perilaku kerja inovatif yang paling tinggi $(M=33.17)$. Teknik statistik independent sampel T-test menunjukan bahwa terdapat perbedaan rata-rata yang signifikan pada perilaku kerja inovatifjika ditinjau berdasarkan aspek jabatan, $t$ (397) $=3.471, p<0.05$. Berdasarkan aspek demografis ini, responden yang berada pada tingkat jabatan managerial memiliki rata- rata skor total perilaku kerja inovatif yang paling tinggi $(M=31.99)$. Teknik statistik ANOVAmenunjukan bahwa terdapat perbedaan rata-rata yang signifikan pada perilaku kerja inovatifjika ditinjau berdasarkan departemen, $F(6,391)=2.792$, $p<0.05$. Berdasarkan aspek demografis ini, responden yang berada pada departemen bisnis memiliki rata-rata skor total perilaku kerja inovatif yang paling tinggi $(M=29.21)$.

Pada analisis tambahan ini, peneliti melakukan uji pos hoc untuk mengetahui kelompok mana yang memiliki perbedaan yang signifikan pada aspek yang memiliki lebih dari dua kategori, yaitu pendidikan dan departemen.

Tabel 4. Uji Post Hoc Aspek Pendidikan dan Departemen

\begin{tabular}{lcc}
\hline \multicolumn{1}{c}{ Kelompok Perbandingan } & Mean Difference & Sig. \\
\hline Pendidikan & & \\
Diploma - Sarjana & 4.320 & $.009^{*}$ \\
Diploma - Magister & 6.856 & $.037^{*}$ \\
Departemen & & \\
Media Service - Publishing WC & 7.749 & .003 \\
Media Service - Bisnis & 6.376 & .018 \\
\hline$* p<0.05 ; * *<<0.01$ level, (two-tailed) & &
\end{tabular}

Perhitungan Post Hoc Tukey menunjukkan rata-rata skor total pada kelompok pendidikan responden penelitian memiliki perbedaan yang signifikan. Berdasarkan Tabel 4.9, diketahui bahwa kelompok tingkat pendidikan sarjana $(\mathrm{M}=30.62, p=$ 0.009) dan kelompok tingkat pendidikan magister $(\mathrm{M}=33.17, p=0.037)$ dibandingkan dengan kelompok tingkat pendidikan diploma $(\mathrm{M}=26.31)$ menunjukan hasil yang signifikan berbeda. Selain itu, perhitungan Post Hoc Tukey juga menunjukkan rata-rata skor total pada kelompok departemen responden penelitian memiliki perbedaan yang signifikan. Berdasarkan Tabel 4.12, diketahui bahwa departemen Publishing WC $(\mathrm{M}=27.84, p=0.003)$ dan departemen Bisnis $(\mathrm{M}=29.21, p=$ 0.018 ) dibandingkan dengan departemen
Media Service ( $M=35.59$ ) menunjukan hasil yang signifikan berbeda.

\section{DISKUSI}

Pada penelitian mengenai hubungan psychological capital dan perilaku kerja inovatif, ditemukan bahwa terdapat hubungan yang signifikan pada kedua variabel tersebut. Penemuan ini sesuai dengan hasil penelitian terlebih dahulu yang dilakukan oleh Abbas dan Raja (2015) dengan populasi penelitian yang berasal dari beragam karyawan yang bekerja di bank, kementerian, perusahaan telekomunikasi, dan perusahaan tekstil di Pakistan. Abbas dan Raja (2015) mengatakan bahwa individu yang tinggi pada psychological capital, lebih mungkin untuk menunjukkan perilaku kreatif atau inovatif di tempat kerja, daripada rekanrekan lainnya yang memiliki 
psychological capital yang rendah. Penelitian yang dilakukan Abbas dan Raja (2015) menunjukkan korelasi yang tergolong rendah berdasarkan Guilford dan Frutcher (1978), yaitu sebesar 0.20. Keterbatasan penelitian tersebut salah satunya terletak pada sampel penelitian yang berasal dari industri-industri yang dirasa tidak memiliki tingkat kebutuhan inovasi yang tinggi, sehingga Abbas dan Raja (2015) menyarankan penelitian berikutnya untuk meneliti hubungan psychological capital dan perilaku kerja inovatif pada industri yang sangat membutuhkan inovasi bagi pertumbuhan organisasi berkelanjutan. Penelitian serupa lainnya yang dilakukan oleh Moegni dan Sulistiawan (2012) menunjukkan bahwa tidak terdapatnya hubungan yang signifikan pada psychological capital dan perilaku kerja inovatif pada dengan sampel penelitian unit kerja di lingkungan perguruan tinggi $X$. Menurut Moegni dan Sulistiawan (2012), hal ini disebabkan oleh perilaku inovasi yang cenderung kurang begitu tampak pada organisasi pemerintahan dibandingkan organisasi swasta atau yang berorientasi waralaba.

Berdasarkan keterbatasan kedua penelitian terdahulu, penelitian kali ini meneliti hubungan psychological capital dan perilaku kerja inovatif pada populasi karyawan yang berasal dari industri kreatif. Industri kreatif memiliki nilai ekonomi yang dinamis, dimana cepat bergerak dan mudah menyesuaikan diri dengan keadaan (Cunningham et al., 2008), sehingga inovasi dirasakan sangat dibutuhkan untuk menyesuaikan dengan perkembangan. Korelasi yang didapatkan dari psychological capital dan perilaku kerja inovatif adalah sebesar 0.448. Menurut Guilford dan Frutcher (1978), nilai korelasi 0.448 tergolong korelasi yang sedang. Hasil korelasi yang tergolong sedang ini menunjukkan tingkat korelasi yang lebih besar dibandingkan hasil penelitian Abbas dan Raja (2015). Peneliti melihat sampel penelitian yang berasal dari industri kreatif dan memiliki nilai inovatif menjadi salah satu faktor yang menyebabkan nilai korelasi penelitian ini lebih besar. Berdasarkan nilai korelasi didapatkan, diketahui bahwa $20.7 \%$ varians dalam perilaku kerja inovatif diprediksi melalui hubungannya dengan psychological capital.

Pada diskusi terkait nilai korelasi yang diperoleh tiap komponen psychological capital, diketahui komponen self efficacy memiliki hubungan yang paling kuat terhadap perilaku kerja inovatif. Self efficacy didefinisikan sebagai keyakinan individu tentang kemampuannya untuk memobilisasi motivasi, sumber daya kognitif, dan tindakan yang diperlukan untuk berhasil melaksanakan tugas tertentu dalam konteks tertentu (Luthans, Youssef, \& Avolio, 2007). Self efficacy yang memiliki hubungan paling kuat dapat dikarenakan self efficacy merupakan keyakinan dasar individu akan kemampuannya, sehingga menjadi hal utama yang harus individu. Pada kaitannya dengan perilaku kerja inovatif, self efficacy yang lebih tinggi memungkinkan untuk melihat tantangan sebagai sesuatu yang dapat diatasi dengan kompetensi yang cukup dan usaha (Bandura, 2008 dalam Luthans, Avolio, \& Norman, 2007), sehingga mereka cenderung memilih untuk mengeksplorasi peluang dan menggenerasikan ide-ide baru untuk mengatasi hal tersebut. Pada perusahaan XYZ, karyawan dengan self efficacy yang tinggi cenderung memiliki tingkat perilaku inovatif yang tinggi juga. Dalam hal ini, peneliti melihat semakin karyawan memiliki keyakinan akan kemampuannya, semakin besar keinginan mereka untuk dapat mengeksplorasi peluang dan 
menggenerasikan idenya menjadi sebuah inovasi yang dapat memberikan manfaat bagi perusahaan.

\section{SIMPULAN}

Temuan penelitian menunjukkan bahwa psychological capital memiliki hubungan yang positif dan signifikan dengan perilaku kerja inovatif di industri kreatif. Hal ini menunjukkan bahwa semakin tinggi psychological capital yang dimiliki oleh karyawan perusahaan $\mathrm{XYZ}$, semakin tinggi pula perilaku kerja inovatif mereka. Sebaliknya, semakin rendah psychological capital yang dimiliki oleh karyawan perusahaan XYZ, semakin rendah pula perilaku kerja inovatif mereka.

Pada hasil penelitian terkait komponen psychological capital, diketahui bahwa keempat komponen psychological capital, yaitu self efficacy, hope, resiliency, dan optimism memiliki hubungan yang positif dan signifikan dengan perilaku kerja inovatif karyawan di industri kreatif perusahaan XYZ. Di antara keempat komponen pada psychological capital, diketahui bahwa self efficacy memiliki hubungan paling kuat terhadap perilaku kerja inovatif karyawan di industri kreatif perusahaan $\mathrm{XYZ}$

\section{SARAN}

Terkait dengan kesimpulan, diskusi, dan keterbatasan penelitian yang telah dijabarkan di atas, peneliti memiliki beberapa saran yang bertujuan untuk penelitian selanjutnya mengenai psychological capital dan perilaku kerja inovatif agar dapat lebih baik lagi. Saran teoretik untuk penelitian berikutnya antara lain dilakukannya penelitian kembali mengenai hubungan psychological capital dan perilaku kerja inovatif pada perusahaan industri kreatif di luar penerbitan dan percetakan, lebih menekankan kerahasiaan data, dan mempertimbangkan jumlah item pada kuesioner yang harus diisi dalam satu waktu. Saran praktis untuk penelitian berikutnya antara lain perusahaan dapat melakukan intervensi terkait psychological capital pada karyawan di perusahaan industri kreatif. Luthans, Youssef, et al. (2006) mengatakan bahwa psychological capital berisifat terbuka terhadap perkembangan dan perbaikan melalui program pelatihan, aktivitas dalam pekerjaan, dan intervensi yang terfokus, yang dapat dijadikan referensi bagi perusahaan. Selain itu, perusahaan juga dapat melakukan pengembangan terhadap komponen psychological capital yang memiliki hubungan lebih kuat terhadap perilaku kerja inovatif, yaitu self efficacy yang diajukan dalam Luthans, Youssef, dan Avolio (2007). Cara yang dapat diaplikasikan perusahaan yaitu penyampaian umpan balik positif yang lebih besar dibandingkan penghargaan finansial dan teknik motivasi lainnya, yang merupakan satu dari empat upaya pengembangan self efficacy pada karyawan yang dapat dilakukan perusahaan, sehingga peningkatan self efficacy akan memengaruhi perilaku kerja inovatif. Untuk dapat menumbuhkan perilaku kerja inovatif pada individu, perusahaan juga dapat lebih memperhatikan faktor-faktor yang mempengaruhi indidu untuk berinovasi, seperti dukungan dari organisasi terhadap karyawan, peningkatan kohesivitas kelompok, hubungan atasan bawahan yang efektif melalui umpan balik dan penghargaan, dan turut melibatkan karyawan dalam keputusan yang hendak diambil perusahaan (West \& Farr, 1989).

\section{DAFTAR PUSTAKA}

Abbas, M., \& Raja, U. (2015). Impact of psychological capital on innovative performance and job stress. 


\section{Canadian Journal \\ Administrative Sciences.}

of

Aiken, L. R. (2000). Psychological testing and assessment. Needham Height. Allyn \& Bacon.

Amabile, T. M. (1988). A model of creativity and innovation in organization. Research in Organizational Behavior, 10, 123167.

Amabile, T. M. (1996). Creativity in Context. Westview Press: Boulder, CO.

Arif, S., Zubair, A., \& Manzoor, Y. (2012). Innovative work behavior and communication climate among employees of advertising agencies. National Institute of Psychology Quaid-i-Azam, 65-72.

Avey, J. B., Reichard, R. J., Luthans, F., \& Mhatre, K. H. (2011). Metaanalysis of the impact of positive psychological capital on employee attitudes, behaviors, and performance. Human Resource Development Quarterly, 127-151.

Avey, J. B., Avolio, B. J., \& Luthans, F. (2011). Experimentally analyzing the process and impact of leader positivity on follower positivity and performance. The Leadership Quarterly, 22(2), 282-294.

Basu, R. \& Green, S. G. (1997). Leadermember exchange and transformational leadership: An empirical examination of innovative behaviors in leadermember dyads. Journal of Applied Social Psychology, 27 (6), 477499.

Bisnis UKM (2012). Artikel [on-line]. Diakses 15 Maret 2015 dari http://bisnisukm.com/mengenalindustri-kreatif-di-indonesia.html

Bunce, D. \& West, M. A. (1995). Personality and perceptions of group climate factors as predictors of individual innovation at work.
Applied Psychology: An International Review, 44, 199-215.

Cozzarelli, C. (1993). Personality and self-efficacy as predictors of coping with abortion.Journal of Personality and Social Psychology, 65, 1224-1237.

Cunningham, S., Ryan, M., Keane, M., \& Ordonez, D. (2008). Financing creative industries in developing countries. Creative Industries and Developing Countries: Voice, Choice and Economic Growth, 65110.

Dessler, G. (2008). Human resources management $\left(11^{\text {th }}\right.$ ed). New Jersey: Pearson Prentice Hall.

Damayanti, R.R. (2013). Pengaruh kepemimpinan transformasional terhadap perilaku kerja inovatif pada karyawan. (Skripsi). Universitas Indonesia. Depok.

De Jong, J. P. J., \& Hartog, D. N. D. (2008). Innovative work behavior: measurement and validation. Scientific Analysis of Entrepreneurship and SMEs, 1-27.

De Jong, J., \& Den Hartog, D. (2003). Leadership as a determinant innovative behavior a conceptual framework. Retrieved from http://www.ondernemerschap.nl/ pdf- ez/h200303.pdf

Dorenbosch, L. W., Engen, M. L., \& Verhagen, M. (2005). On-the-job innovation: The impact of job design and human resource management through product ownership. Creativity and Innovation Management, 14(2), 129-141.

Friedenberg, L. (1995). Psychological testing : Design, analysis, and use. Boston : Allyn and Bacon.

Garet, H. (1960). Statistic in psychology and education (5th ed). New York: Longman, Green \& Company. 
Gravetter, F. J., \& Forzano, L.B. (2012). Research methods in behavioral science. California: Wadsworth Cengage Learning.

Ghazali, A (2015, 16 Februari). Pemetaan industri kreatif di Indonesia. Artikel [on-line]. Diakses 15 Maret 2015 dari http://www.cielsbm.org/pemetaanindustri-kreatif-di-indonesia.html

Guilford, J. P., \& Frutcher, B. (1978). Fundamental statistics in psychology and education $\left(6^{\text {th }} \mathrm{ed}\right)$. New York: McGraw-Hill, Inc.

Hair. J. F., Black. W. C., Babin. B. J., \& Anderson. R. E. (2010). Overview of multivariate methods. Pearson Prentice Hall.

Hammond, M.M., Farr, J.L., Neff, N.L., Schwall, A.R., \& Zhao, X. (2011). Predictors of individual level of innovation at work: A meta analysis. Psychology of Aesthetics, Creativity, and the Arts, 5(1), 90103.

Hsiao, H. C., Chang, J. C., Ling Tu, Y., \& Chen, S. C. (2011). The impact of self efficacy on innovative work behavior for teachers. International Journal of Social Science and Humanity, 1(1), 3136.

Hsu, M. L A., Hous, S. T., \& Fan, H. L. (2011). Creative self-efficacy and innovative behavior in a service setting: optimism as a moderator. Journal of Creative Behavior, 45(4), 258-272.

Janssen, O. (2000). Job demands, perception of effort-reward fairness and innovative work behavior. Journal of Occupational and Organizational Psychology, 73(3), 287-302.

Janssen, O. (2003). Innovative behaviour and job involvement at the price of conflict and less satisfactory relations with co-workers. Journal of Occupational and Organizational Psychology, 76, 347-364.

Janssen, O. (2004). How fairness perceptions make innovative behavior more or less stressful. Journal of Organizational Behavior, 25(2), 201-16.

Janssen, O. \& Van Yperen, N.W.

(2004). Employees' goal orient ations, the quality of leadermember exchange, and the outcomes of job performance and job satisfaction. Academy of Management Journal, 47(3), 368384.

Jaya, E. S., \& Mangundjaya, W. (2010). Examining the Factorial Validity of Indonesian General Psychological Capital Questionnaire (I- GPCQ). Diakses dari

http://www.academia.edu/7147734 /The_Impact_of_Workplace_WellBeing_and_Psychological_Capital to the Individual_Readiness_for Change

Kaplan, R., \& Saccuzo, D. (2005). Psychological testing: Priciples, application, and issues ( $6^{\text {th }}$ ed.). Belmount: Wadsworth.

Kanter, R. (1988), When a thousand flowers bloom: structural, collective, and social conditions for innovation in organizations, in Staw, B.M. and Cummings, L.L. (Eds). Research in Organizational Behavior, 10, 169-211.

Kerlinger, F. N. (2000). Foundations of behavioral research ( $2^{\text {nd }}$ ed). New York: New York University.

Kumar, R. (1999). Research metodology: A step-by-step guide for beginners. Malaysia: Sage Publications.

Luthans, F. (2002). The need for and meaning of positive organizational 
behavior. Journal of Organizational Behavior, 23, 695706.

Luthans, F., Avolio, B. J., Avey, J. B., \& Norman, S. M. (2007). Positive psychological capital: Measurement and relationship with performance and satisfaction. Personnel Psychology, 60, 541572.

Luthans, F., \& Youssef, C. M. (2007). Emerging positive organizational behavior. Journal of Management, 33, 321-349.

Luthans, F., Youssef, C. M., \& Avolio, B. J. (2007). Psychological capital: Developing the human competitive edge. USA : Oxford University Press, Inc.

Luthans, F., Avey, J. B., Smith, R. C., \& Li, W. (2008). More evidence on the value of Chinese workers' psychological capital: A potentially unlimited competitive resource?. The International Journal of Human Resource Management, 19, 818-827.

Kleysen, R. F., \& Street, C. T. (2001). Towards a multi-dimensional measure of individual innovative behavior. Journal of Intellectual Capital, 2 (3), 284-296.

Michaelis, B., Buch, V., Stegmaier, R. \& Sonntag, K. (2008). A recipe for effective and non-stressful change: The role of organizational support and fairness. The Seventh International Conference on Occupational Stress and Health, 2004 (Washington, DC).

Moegni, N., \& Sulistiawan, J. (2012). Pengaruh Psychological Capital terhadap Innovative Work Behaviors: Efek Moderasi Perceived Procedural Fairness. Majalah Ekonomi, 125-134.

Moore, I. (2013). Cultural and creative industries concept: A historical perspective. Social and Behavioral Sciences, 110, 738 - 746.

Ornstein, S., Cron, W. L., \& Slocum, J. W. (1989). Life Stage Versus Career Stage: A Comparative Test of The Theories of Levinson and Super. Journal of Organizational Behavior, 10(2), 117-133.

Oukes, T. (2010). Innovative work behavior: a case study at a tire manufacturer. Belanda: University of Twente.

Parman, A., Subagiyo, Chairi, B., Erwidodo, Kresnarini, H, I., \& Suseno, E. (2008). Pengembangan Ekonomi Kreatif Indonesia 2025. Indonesia : Departemen Perdagangan Republik Indonesia. Diakses dari http://dgiindonesia.com/wpcontent/uploads/2009/05/buku-1rencana-pengembangan-ekonomikreatif-indonesia-2009.pdf

Patterson, F., Kerrin, M., \& GattoRoissard, G. (2009). Characteristics and behaviours of innovative people in organizations. NESTA ResearchReports. London: Nesta.

Peterson, S. J., Luthans, F., Avolio, B. J., Walumbwa, F. O., \& Zhang, Z. (2011). Psychological capital and employee performance: a latent growth modeling approach. Personnel Psychology, 64, 427450.

Ramamoorthy, N., Flood, P.C., Slattery, T., \& Sardessai, R. (2005). Determinants of innovative work behaviour: development and test of an integrated model. Creativity and Innovation Management, 14(2), 142-150.

Royal, K. (2011). Understanding Reliability in Higher Education Student Learning Outcomes Assessment. Dalam D. Hopen (Ed). Quality Approaches in 
Higher Education. Milwaukee: American Society for Quality.

Scott, S. G., \& Bruce, R. A. (1994). Determinants of innovative behavior: A path model of individual innovation in the workplace. Academy of Management Journal, 37 (3), 580607.

Schermuly, C. C., Meyer, B., \& Dammer, L. (2013). Leadermember exchange and innovative behavior. Journal of Personnel Psychology, 12(3), 132-142.

Seibert, S. E., Kraimer, M. U., \& Crant, J. M. (2001). What do proactive people do? A longitudinal model linking proactive personality and career success. Personnel Psychology, 54, 845-874.

Spreitzer, G.M. (1995), Psychological empowerment in the workplace: Dimensions, measurement, and validation, Academy of Management Journal, 38, 1442146.

Suara Pembaruan (November, 2012). Artikel [on-line] Diakses 15 Maret 2015 dari http://sp.beritasatu.com/ekonomida nbisnis/dorong-pertumbuhanindustri-kreatif-di-indonesia/26954

Sweetman, D., Luthans, F., Avey, J. B., \& Luthans, B. C. (2010). Relationship between positive psychological capital and creative performance. Canadian Journal of Administrative Sciences, 28(1), 413.
Tim Studi Ekonomi Kreatif, (2014). Artikel [on-line]. Diakses 15 Maret 2015 dari http://program.indonesiakreatif.net /research/kontribusi-ekonomikreatif-indonesia/

UNCTAD. (2010). Creative Economy Report 2010. Diakses dari http://unctad.org/en/Docs/ditctab20 103 en.pdf

UNESCO. (2005). Understanding Creative Industries. Diakses dari http://portal.unesco.org/culture/es/f iles/30297/11942616973cultural_st at_EN.pdf/cultural_stat_EN.pdf

Utami, L. D., \& Lantu, D. C. (2014). Development competitiveness model for small medium enterprises among the creative industry in bandung. Social and Behavioral Sciences, 115, 305323.

Vinarski-Perets, H., Binyamin, G., \& Carmeli, A. (2011). Subjective relational experiences and employee innovative behavior in the workplace. Journal of Vocational Behavior, 78(2), 290304.

Waenink, E. (2012). Creating innovation in employees, the effect of competences on innovative work behavior and the moderating role of human resources practices. (Master's Thesis). Universiteit Twente, Enschede.

West, M.A., \& Farr, J.L. (1989). Innovation at work: Psychological perspectives. Social Behavior, 4, 15-30. 